\title{
Distraction methods for pain relief of cancer children submitted to painful procedures: systematic review*
}

\author{
Métodos de distração para o alívio da dor em crianças com câncer submetidas a \\ procedimentos dolorosos: revisão sistemática
}

Elaine Barros Ferreira1, Flávia Oliveira de Almeida Marques da Cruz¹, Renata Cristina de Campos Pereira Silveira², Paula Elaine Diniz dos Reis ${ }^{1}$

${ }^{*}$ Received from University of Brasilia, School of Health Sciences, Nursing Department, Brasilia, DF, Brazil.

DOI 10.5935/1806-0013.20150028

\section{ABSTRACT}

BACKGROUND AND OBJECTIVES: Pain is one of the most persistent cancer symptoms. Non-pharmacological therapies are potential sources for cancer children care and should be considered alternatives for handling cancer signs and symptoms. This study aimed at identifying effective distraction interventions for pain relief and control of cancer children submitted to invasive procedures.

CONTENTS: This is a systematic review carried out in electronic databases LILACS, CINAHL, CENTRAL Cochrane Library and Pubmed, using the combination of controlled and uncontrolled keywords: child, pain, cancer and distraction. Ten studies were identified addressing distraction as intervention for venous, muscle and subcutaneous punctures, and procedures related to bone marrow aspiration and lumbar puncture.

CONCLUSION: Among identified interventions, there are virtual reality, practices such as blowing soap bubbles, use of warm pillows, party blower, electronic toys, among other selfselected interventions (music, games, books). Most interventions are easy to implement considering their low cost and are useful for health professionals looking at enhancing pediatric patients' assistance with regard to pain management.

Keywords: Child, Children care, Pain, Pediatrics, Tumors.

1. University of Brasília, School of Health Sciences, Nursing Department, Brasília, DF, Brazil.

2. University of São Paulo, School of Nursing of Ribeirão Preto, Ribeirão Preto, SP, Brazil.

Submitted in July 03, 2014

Accepted for publication in April 24, 2015.

Conflict of interests: none - Sponsoring sources: none.

Correspondence to:

Elaine Barros Ferreira

Departamento de Enfermagem, Faculdade de Ciências da Saúde da Universidade de Brasília

Campus Darcy Ribeiro. Asa Norte

70910-900 Brasília, DF, Brasil.

E-mail: elaine.barrosf@gmail.com

(c) Sociedade Brasileira para o Estudo da Dor

\section{RESUMO}

JUSTIFICATIVA E OBJETIVOS: A dor assume papel de destaque dentre os mais persistentes sintomas do câncer. As terapias não farmacológicas são fontes potenciais para a assistência das crianças com câncer e devem ser consideradas como alternativas para o manuseio de sinais e sintomas oncológicos. O objetivo deste estudo foi identificar intervençôes efetivas de distraçáo para o alívio e controle da dor em criança com câncer quando submetida a um procedimento invasivo.

CONTEÚDO: Trata-se de revisão sistemática, cuja busca dos estudos primários foi realizada nas bases de dados eletrônicas LILACS, CINAHL, Biblioteca Cochrane CENTRAL e Pubmed, utilizando-se a combinação dos descritores controlados e náo controlados: child, pain, cancer, e distraction. Foram identificados 10 estudos, que abordavam a distração como intervenção para punçôes venosas, musculares, subcutâneas e procedimentos relacionados à aspiração de medula óssea e punção lombar.

CONCLUSÃO: Dentre as intervençôes identificadas está o uso da realidade virtual, práticas como soprar bolhas de sabão, uso da almofada aquecida, soprador de festa, brinquedo eletrônico, dentre outras intervençóes autosselecionadas (música, jogos, livros). As intervençôes são, em sua maioria, de fácil programação considerando seu baixo custo e úteis aos profissionais de saúde que buscam aprimorar a assistência ao paciente pediátrico no que se refere ao manuseio da dor.

Descritores: Criança,Cuidado da criança, Dor, Neoplasias, Pediatria.

\section{INTRODUCTION}

Pain is one primary cancer symptom ${ }^{1}$, being experienced by all cancer children, with more than $70 \%$ of them having severe pain. So, there is the need to recognize this pain, even if subjectively understood, thus avoiding its inadequate treatment ${ }^{2}$.

Common during diagnosis and management, pain may result from painful procedures, disease progression or nerve compression, among other factors ${ }^{3}$. It is important to note 
that invasive procedures, common in different moments of the therapy imposed to cancer patients, induce the most distressing and difficult pain experiences for children and their parents, justifying further focus on handling pain related to such procedures ${ }^{4}$.

Currently, adequate pain management is becoming increasingly relevant, since it is considered indicator both of quality of life (QL) and of the assistance itself5, being that such management should take into consideration physical, psychosocial and spiritual aspects of patients and their families ${ }^{6}$. So, one should understand the need for psychological support and the use of non-pharmacological methods, as well as teaching strategies aiming at handling pain, thus decreasing behavioral impacts generated during invasive procedures ${ }^{7}$.

Non-pharmacological pain control therapies are potential sources for cancer children assistance and should be seen as alternatives to handle cancer signs and symptoms. In addition, it is critical to prioritize the investigation of their most different application manners and of their results to manage other signs and symptoms different from pain, such as nausea, vomiting and anxiety ${ }^{8}$. Knowledge coming from available evidences is an important tool for the identification of different types of non-pharmacological therapies to prevent or decrease invasive procedure-related pain ${ }^{4}$.

This study aimed at identifying in the scientific literature effective distraction interventions for pain relief and control in cancer children submitted to invasive procedures, summarizing identified results, so that health professionals may use such information for the benefit of better assistance to pediatric patients in terms of pain management. We hope that the summary of existing knowledge on this subject may contribute to enhance the skills needed by health professionals when dealing with such patients.

\section{CONTENTS}

This is a systematic literature review, aiming at gathering all scientific evidences meeting pre-established eligibility criteria, to answer a specific research question. So, essential features of this review are: clear objective with pre-established selection criteria; explicit methodological reproducibility; systematic search to identify all studies which could meet eligibility criteria; evaluation of primary studies results, as well as a summary of their characteristics and results ${ }^{9}$.

The guiding question of the research - "Which effective distraction interventions are used for pain relief and control in cancer children submitted to invasive procedures?" - was developed using the PICO strategy from the acronym: Patient, Intervention, Comparison and Outcomes. PICO strategy has shown to be efficient for effective evidences recovery, because it focuses on the objective of the research and prevents unnecessary searches ${ }^{10}$.

Search went on until June 2014 in the following databases: LILACS, CINAHL, Cochrane Central Register of Con- trolled Trials (CENTRAL) and Pubmed. The following descriptors were used for the search: child, pain, cancer and distraction. Boolean operator "AND" was used for crosschecking among descriptors, establishing a single crosscheck as search strategy, namely: child AND pain AND cancer AND distraction.

Inclusion criteria were clinical trials in Portuguese, English and Spanish addressing distraction interventions for pain relief and control in cancer children submitted to invasive procedures. Publication period limits were not adopted.

We have identified 79 articles of which titles and abstracts were read, which allowed a priori selection of 15 studies. Since not all studies had in the abstract their methodological design or did not precisely indicate participants' age and could be or not studies involving cancer children, type of outcome and intervention being used, it was necessary to initially examine in full all pre-selected studies. So, from identified studies, five have not met inclusion criteria, being left 10 articles as observed in figure 1. It is important to note that repeated studies in one or more databases were considered only once.

Articles data extraction and evaluation were independently made in pairs and divergences were discussed to reach a consensus.

Selected articles were reviewed by means of their full reading and filling of data collection tool developed by the authors. Then, articles were classified according to essay methodological quality, considering Jadad Scale ${ }^{11}$ (Table 1).

Tem articles were identified which addressed distraction as intervention to remove children's focus from the invasive

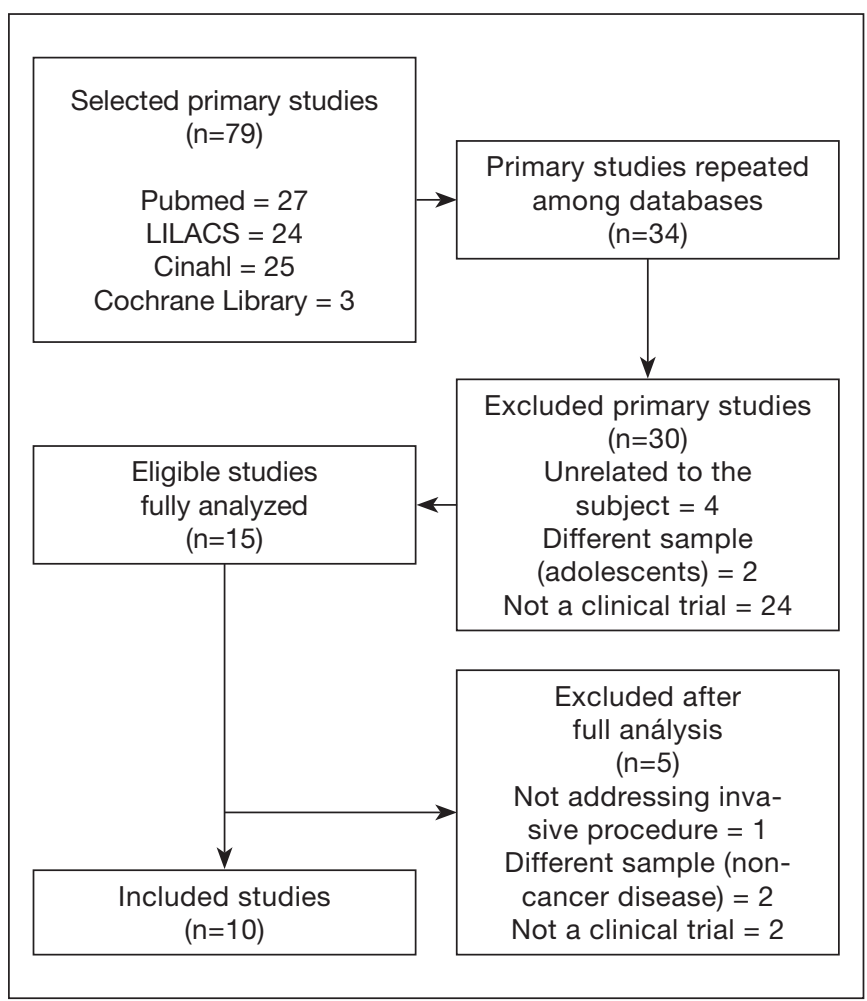

Figure 1. Selection criteria for studies. Brasília-DF, Brazil, 2014 
procedure to which they were being submitted. With regard to language, all articles were published in English. Publication years varied between 1988 and 2009 and age groups of studied sample has varied from 2 years to 19 years of age (Table 1).

All selected articles used some way of non-pharmacological intervention based on distraction, such as behavioral cognitive intervention for venous, muscle and subcutaneous punctures, and procedures related to bone marrow aspiration and lumbar puncture (Table 1).

According to the articles, interventions were in general use- ful for pain relief or have shown decreased levels of anxiety, distress, affliction or fear present during invasive procedures (Table 2).

To evaluate the methodological quality of selected studies, Jadad Scale was applied, which evaluates criteria related to randomization, blinding and reasons for losing or excluding subjects from the study. According to these criteria, no study was considered of high-quality, as seen in table 1, which contains scores followed by justification. No evaluated study was characterized as double-blind, which has implied lower scores.

Table 1. Distribution of articles according to year, internal validity according to JADAD scale, sample age group, invasive procedure, applied intervention, evaluation scales and objectives. Brasília-DF, Brazil, 2014

\begin{tabular}{|c|c|c|c|c|c|c|c|}
\hline Authors & JADAD & Sample size & $\begin{array}{l}\text { A ge } \\
\text { group }\end{array}$ & $\begin{array}{l}\text { Invasive pro- } \\
\text { cedure }\end{array}$ & $\begin{array}{l}\text { Distraction } \\
\text { intervention }\end{array}$ & $\begin{array}{l}\text { Evaluation } \\
\text { scales }\end{array}$ & Objective \\
\hline $\begin{array}{l}\text { Hedén, } \\
\text { Von Essen, } \\
\& \quad \text { Ljung- } \\
\text { man }^{12}\end{array}$ & $\begin{array}{l}3 \\
\text { Study not des- } \\
\text { cribed as dou- } \\
\text { ble-blind }\end{array}$ & $\begin{array}{l}\mathrm{n}=28 \\
\mathrm{n}=14 \\
\text { Intervention } \\
\text { group blowing } \\
\text { soap bubbles } \\
\mathrm{n}=14 \\
\text { Intervention } \\
\text { group warm } \\
\text { pad }\end{array}$ & $\begin{array}{l}2 \text { to } 7 \\
\text { years }\end{array}$ & $\begin{array}{l}\text { Subcut a- } \\
\text { neous punc- } \\
\text { ture for TI- } \\
\text {-CVC acess }\end{array}$ & $\begin{array}{l}\text { b l o w ing } \\
\text { soap bub- } \\
\text { bles } \\
\text { Warm pad }\end{array}$ & VAS & $\begin{array}{l}\text { To evaluate whether chil- } \\
\text { dren had less fear, dis- } \\
\text { tress and pain at routine } \\
\text { puncture when submitted } \\
\text { to some interventions: } \\
\text { blowing soap bubbles our } \\
\text { warm pad, as compared } \\
\text { to usual established care. }\end{array}$ \\
\hline 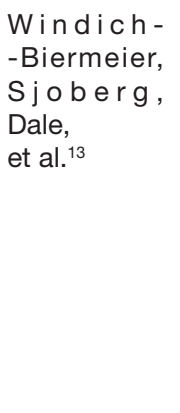 & $\begin{array}{l}2 \\
\text { Study not de- } \\
\text { scribed as } \\
\text { double-blind. } \\
\text { No description } \\
\text { of removal and } \\
\text { waiver of the } \\
\text { sample. }\end{array}$ & $\begin{array}{l}\mathrm{n}=50 \\
\mathrm{n}=28 \\
\text { Control group } \\
\mathrm{n}=22 \\
\text { Intervention } \\
\text { group }\end{array}$ & $\begin{array}{l}5 \text { to } 18 \\
\text { years }\end{array}$ & $\begin{array}{l}\text { Subcut a- } \\
\text { neous punc- } \\
\text { ture for TI- } \\
\text {-CVC access } \\
\text { and venous } \\
\text { puncture }\end{array}$ & $\begin{array}{l}\text { Self-selec- } \\
\text { ted inter- } \\
\text { ventions, } \\
\text { a } \mathrm{m} \text { o } \mathrm{n} \mathrm{g} \\
\text { them: bub- } \\
\text { bles, chal- } \\
\text { I e } \mathrm{n} \text { i i g } \\
\text { book, vir- } \\
\text { tual reality } \\
\text { glasses or } \\
\text { portable } \\
\text { games }\end{array}$ & $\begin{array}{ll}\text { CAS } & \\
\text { Glasses } & \text { Fear } \\
\text { Scale } & \\
\text { OSBD } & \end{array}$ & $\begin{array}{l}\text { To evaluate the effect of } \\
\text { self-selected distractions } \\
\text { on pain, fear and distress } \\
\text { in cancer children and } \\
\text { adolescents submitted to } \\
\text { procedures such as ve- } \\
\text { nous access, via subcuta- } \\
\text { neous puncture, to TI-CVC } \\
\text { or venous punctures. }\end{array}$ \\
\hline 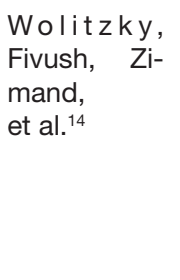 & $\begin{array}{l}2 \\
\text { Study not de- } \\
\text { scribed as } \\
\text { double-blind. } \\
\text { No description } \\
\text { of randomiza- } \\
\text { tion method. }\end{array}$ & $\begin{array}{l}\mathrm{n}=20 \\
\mathrm{n}=10 \\
\text { Experimental } \\
\text { group -Virtual } \\
\text { reality } \\
\mathrm{n}=10 \\
\text { Control group }\end{array}$ & $\begin{array}{l}7 \text { to } 14 \\
\text { years }\end{array}$ & $\begin{array}{l}\text { Subcuta- } \\
\text { neous punc- } \\
\text { ture for TI- } \\
\text {-CVC access }\end{array}$ & $\begin{array}{l}\text { Virtual re- } \\
\text { ality }\end{array}$ & $\begin{array}{l}\text { VAS } \\
\text { How-I-F e I } \\
\text { Questionnaire } \\
\text { Heart rate } \\
\text { CHEOPS }\end{array}$ & $\begin{array}{l}\text { To evaluate the effective- } \\
\text { ness of virtual reality as } \\
\text { behavioral intervention to } \\
\text { decrease distress during } \\
\text { TI-CVC access procedure. }\end{array}$ \\
\hline
\end{tabular}


Table 1. Distribution of articles according to year, internal validity according to JADAD scale, sample age group, invasive procedure, applied intervention, evaluation scales and objectives. Brasília-DF, Brazil, 2014

\begin{tabular}{|c|c|c|c|c|c|c|c|}
\hline Authors & JADAD & Sample size & $\begin{array}{l}\text { A g e } \\
\text { group }\end{array}$ & $\begin{array}{l}\text { Invasive pro- } \\
\text { cedure }\end{array}$ & $\begin{array}{l}\text { Distraction } \\
\text { intervention }\end{array}$ & $\begin{array}{l}\text { Evaluation } \\
\text { scales }\end{array}$ & Objective \\
\hline $\begin{array}{l}\text { Dahlquist, } \\
\text { P e nd le y, } \\
\text { Landthrip,et } \\
{\text { al. }{ }^{16}}^{\text {a }}\end{array}$ & $\begin{array}{l}2 \\
\text { Study not de- } \\
\text { scribed as } \\
\text { double-blind. } \\
\text { No description } \\
\text { of randomiza- } \\
\text { tion method. }\end{array}$ & $\begin{array}{l}\mathrm{n}=29 \\
\text { No description } \\
\text { of sample of } \\
\text { each group. }\end{array}$ & $\begin{array}{l}2 \text { to } 5 \\
\text { years }\end{array}$ & $\begin{array}{l}\text { Subcut a- } \\
\text { neous punc- } \\
\text { ture for TI- } \\
\text {-CVC access } \\
\text { and muscle } \\
\text { injections }\end{array}$ & $\begin{array}{l}\text { Electronic } \\
\text { toy }\end{array}$ & OSBD & $\begin{array}{l}\text { To evaluate a distraction } \\
\text { intervention developed to } \\
\text { decrease distress of pre- } \\
\text {-school children submitted } \\
\text { to repeated chemotherapy } \\
\text { injections. }\end{array}$ \\
\hline
\end{tabular}

Broom e, 3

Rehwaldt \& Study not de-

Fogg ${ }^{17}$

\begin{abstract}
scribed as
\end{abstract} double-blind.

\section{$\mathrm{n}=19$}

No description

of sample of

each group.

\section{4 to $18 \mathrm{~L} \mathrm{u} \mathrm{m} \mathrm{b} \mathrm{a} r$ Relaxation, Oucher Scale years puncture distraction and imagi- OSBD nation}

To examine how specific individual differences and contextual variables influence children/adolescents response to painful procedures during cancer treatment and how do such variables influence the effectiveness of relaxation, distraction and imagination.

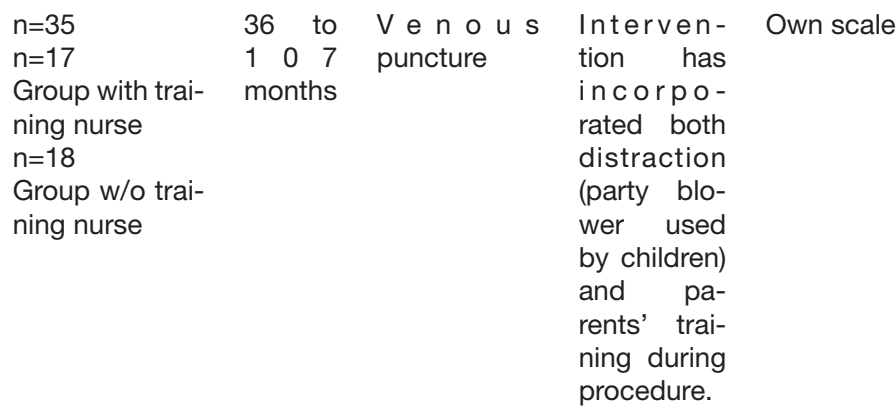

$\begin{array}{lll}3 \text { to } 9 \quad \text { Ven o u s } & \text { Use of par- } \\ \text { years } & \text { puncture } & \text { ty blower } \\ & \text { by means } \\ & \text { of parent } \\ & \text { training and } \\ & \text { pos it ive } \\ & \text { reinforce- } \\ & \text { ment }\end{array}$

VAS

$\begin{array}{llll}6 \text { to } 18 & \text { Bone mar- } & \text { Verbal dis- } \\ \text { years } & \text { row aspi- } & \text { traction and } \\ & \text { ration and/ } & \text { sensory in- } \\ & \text { or lumbar formation } \\ & \text { puncture }\end{array}$

\section{OSBD}

Self-reported fear and pain measures Physiological anxiety measure

$\begin{array}{lll}\mathrm{n}=48 & 3 \text { to } 6 & \text { Bone mar- } \\ \text { No description } & \text { years } & \text { row aspira- } \\ \text { of sample of } & \text { and } 7 & \text { tion } \\ \text { each group. } & \text { to } 10 & \\ & \text { years } & \end{array}$

Hypnosis, PBRS-R "imagina- Observational tive event", scale for pain behavioral and anxiety distraction
To analyze a behavioral intervention developed to decrease stress in children submitted to venous puncture for cancer treatment.

To investigate a behavioral intervention incorporating parents training, attention distraction and positive reinforcement to control children's affliction/distress during invasive cancer treatment.

To combine two behavioral interventions with two coping styles and to evaluate its effectiveness to minimize fear and pain in pediatric cancer patients who have experienced several invasive procedures.

To compare the effectiveness of hypnosis, "imaginative involvement", behavioral distraction and standard medical practice to decrease pain, distress and anxiety in leukemia children during bone marrow aspiration.
Self-report scale developed and validated for the study

CAS = color analog scale; TI-CVC = totally implanted central venous catheter; VAS = visual analog scale; OSBD = Observation Scale of Behavioral Distress; CHEOPS $=$ Children's Hospital of Eastern Ontario Pain Scale; PBRS-R = Procedure Behavior Rating Scale Revised. 
Table 2. Distribution of articles according to results and conclusions. Brasília-DF, Brazil, 2014

\begin{tabular}{|c|c|}
\hline Authors & Results and Conclusions \\
\hline $\begin{array}{l}\text { Hedén, Von Essen e } \\
\text { Ljungman }^{12}\end{array}$ & $\begin{array}{l}\text { According to parents' reports, children had less fear with submitted to proposed intervention as compared to } \\
\text { standard treatment }(p<0.001) \text {. Children had less fear }(p<0.05) \text { and distress }(p<0.05) \text { when submitted to standard } \\
\text { treatment associated to the activity of blowing soap bubbles as compared to standard treatment alone }(n=14) \text {, } \\
\text { and less fear when submitted to standard treatment associated to warm pillow as compared to standard tre- } \\
\text { atment alone }(p<0.05) \text {. }\end{array}$ \\
\hline & $\begin{array}{l}\text { Pain and fear reported by children were significantly correlated }(p=0.01) \text { in treatment groups, but not signifi- } \\
\text { cantly different among groups. Intervention group participants have shown significantly less fear }(p<0.001) \text { and } \\
\text { distress ( } p=0.03) \text {, as evaluated by the nurse, and less fear }(p=0.07) \text {, as evaluated by parents. All intervention } \\
\text { group parents have stated that puncture was better tolerated due to distraction. }\end{array}$ \\
\hline
\end{tabular}

Wolitzky, Fivush, Zimand, Children of both groups were not different in levels of anxiety and distress, or heart rate values before the proet al. ${ }^{14}$ cedure. During the procedure, groups were different in pain and heart rate measures, indicating that children under virtual reality have not suffered so much pain and anxiety and tend to be slightly less afflicted as compared to controls.

Gershon, Zimand, Pickering, et al. ${ }^{15}$

Children of the distraction group with virtual reality had significantly lower heart rates as compared to control group children $(p<0.05)$. Non-verbal distress indices indicated that control group individuals had more muscle tension as compared to those in the distraction group with virtual reality. Even more tension was identified on the leg both in the group with virtual reality and the group without virtual reality $(p<0.05)$.

Dahlquist, Pendley, Landthrip, et al. ${ }^{16}$

Broome, Rehwaldt \& Fogg $^{17}$

Manne, Bakeman, Jacobsen, et al. ${ }^{18}$

Manne, Redd, Jacobsen, et al. ${ }^{19}$

Kuttner, Bowman \& Teasdale ${ }^{21}$
Children receiving distraction intervention had decreased distress behavior and lower levels of anxiety as compared to control group children, according to parents and nurses evaluation. Results suggest that adequately developed activity - varied, multi-sensory distraction, requiring active cognitive processing and active motor responses might be a feasible and low-cost alternative for preschoolers.

There has been pain improvement during the period of five months, but distress behavior has not changed. At baseline visit, temperament, decreased activities, less persistence and distraction parameters were related to higher pain intensity reports, but not to distress behavior. However, after five months, only good mood parameter was related to better pain reports. Time spent by parents and children performing techniques, comfort of their performance and their efficacy were also correlated to good mood.

Distraction technique was associated with less crying. Health professional encouragement and early procedure intervention have not indicated improvement on intervention effectiveness. Older children and those less distressed during initial procedure stage were less prone to reject the intervention.

Results indicate that distress classifications observed by children, children's affliction according to parents' evaluation and self-evaluation of parents distress were decreased after behavioral intervention and were maintained along three intervention attempts. Physical contention to manage children's behavior was also decreased. Pain reported by children, and nursing evaluation of distress were not affected.

There were no differences between groups in fear or pain self-report. Children receiving information had higher heart rates as compared to those using distraction, regardless of coping style. The level of previous experience with invasive procedures may be an important factor for the preferred coping style when managing these patients' pain.

In the first intervention session, observational evaluations of distress have shown reductions for the younger group under hypnotic treatment, while the group of older children had reductions in both treatment conditions for pain and anxiety. In the second intervention session, all groups had reductions and control group was seemingly contaminated. The hypnotic method with its internal focus had an everything-or-nothing effect, and distraction has required coping skills to be learned throughout one or more sessions.

\section{DISCUSSION}

Non-pharmacological interventions used in selected studies differ among them with regard to the type of strategy. It is predominant the use of behavioral interventions using distraction as resource to control and manage pain in cancer children submitted to invasive procedures, as well as for the evaluation of behavioral factors, such as distress, affliction, fear and anxiety.
Among distraction techniques found in the literature there is the use of electronic toys, relaxation, imagination, soap bubbles, warm pillow, self-selected distractions, party blower and virtual reality, being the two latter methods the most commonly used among selected articles.

With regard to virtual reality, studies have pointed that such intervention may be effective for children submitted to painful and distressing procedures ${ }^{14,15}$. It is important to consider in which procedures such intervention may be used and un- 
der which conditions, since problems have been raised about low painful stimulation related to evaluated invasive procedure, that is, totally implanted venous catheter puncture, and the use of topic local anesthetics before the procedure ${ }^{15}$. One should also consider that some studies have reported that topic local anesthetics would be used at puncture site, which could interfere with results ${ }^{12,13,15}$.

Still about virtual reality, it is inferred from the literature the need for further studies about the application of this technology taking into consideration its cost-effectiveness ratio $^{15}$. Further studies should compare virtual reality efficacy to other distraction methods ${ }^{14}$, considering the high cost of some equipment used for virtual reality as compared to other distraction or amusement techniques, such as soap bubbles our warm pillow, which are simple, low-cost interventions not requiring professionals workload increase, being this often considered a barrier for the adoption of unconventional treatment means ${ }^{12}$.

Plural analysis of children's behavior face to invasive procedures, including painful stimulation, is performed by means of different evaluation scales. Such scales are applied before, during and after the use of non-pharmacological interventions. Importance should be given to visual analog scale (VAS) and physiological evaluation taking into consideration parameters such as heart rate (Table 1). Physiological evaluation measures are valued in articles as method of analysis since they have brought significant results to studies ${ }^{14,15,20}$, being even considered tools to be included in the evaluation of future studies of those who have not used them yet ${ }^{19}$.

Involving the family during care is critical. Studies have shown that parents are able to play an active role in supporting and training their children during the procedure ${ }^{13}$, fact that is confirmed by other studies which have also counted on parents' role during intervention and/or during evalua$\operatorname{tion}^{12,14-19,21}$.

The study working with party blower ${ }^{18,19}$, has also effectively incorporated parents in the intervention process, even evaluating their distress during procedure ${ }^{19}$. Parents-children relationship favors coping with and accepting the distraction intervention, during knowingly painful procedures. Manne et al. ${ }^{18}$ suggest that the link between parents and children is extremely relevant for the effectiveness of the intervention when it depends on the training offered by parents to children.

It was observed among selected studies that different distraction forms may be considered effective strategies for pain relief and control, in addition to decreasing distress, affliction, fear and anxiety; however the literature shows the need for expansion and analysis with regard to study samples. A large part of the studies state that sample was small ${ }^{12,18-20}$ indicating in their analyses the need for experiments with larger samples $^{13-15,18,20}$.

The wide variety of age groups (younger age $=2$ years and older age $=19$ years) causes major divergences, since it simultaneously encompasses different development stages and cognitive capacities, being even important to consider the use and evaluation of adequate devices for younger children ${ }^{14,15}$. On the other hand, Manne et al. ${ }^{18}$ state that, according to their study data, older children tend to cooperate and present more positive results to distraction interventions as compared to younger children, for not rejecting distraction that much.

It should be noted that studies have indicated as fragility the fact that they have not followed criteria with regard to evaluators blinding ${ }^{14,15,19}$. Aiming at preventing or decreasing possible biases of analyses and interpretation of results, we suggest the development of further studies with blind evaluators ${ }^{14}$.

\section{CONCLUSION}

The study allowed for the identification of evidences available in the scientific literature with regard to pain relief and control in cancer children using distraction practices. Among them there are virtual reality, practices such as blowing soap bubbles, use of warm pillow, party blower, electronic toys, among other self-selected interventions (music, games, books). Most interventions are easy to implement, considering their low cost, and are useful for health professionals looking at enhancing pediatric patients' assistance with regard to pain management.

Major study limitations were: decreased number of participants both in experimental and control groups, which does not allow for more robust conclusions. Distraction techniques were varied and were not deeply described, considering the broad guiding question, which makes difficult to elect the most effective distraction intervention and for which invasive procedure. In addition, studies should have worked with more specific age groups, since development competences of each child are quite different and interaction and response to stress are age-dependent.

\section{REFERENCES}

1. Monteiro AC, Rodrigues BM, Pacheco ST. O enfermeiro e o cuidar da criança com câncer sem possibilidade de cura total. Esc Anna Nery. 2012;16(4):741-6.

2. Menossi MJ, Lima RA, Correa AK. [Pain and the challenge of interdisciplinarity in child care]. Rev Lat Am Enfermagem. 2008;16(3):489-94. English, Portuguese, Spanish.

3. Thrane $S$. Effectiveness of integrative modalities for pain and anxiety in children and adolescents with cancer: a systematic review. J Pediatr Oncol Nurs. 2013;30(6):32032.

4. Landier W, Tse AM. Use of complementary and alternative medical interventions for the management of procedure-related pain, anxiety, and distress in pediatric oncology: an integrative review. J Pediatr Nurs. 2010;25(6):566-79.

5. Kurita GP, Pimenta CA, de Oliveira Júnior JO, Caponeiro R. [Alterations in attention and cancer pain treatment]. Rev Esc Enferm USP. 2008;42(1):143-51. Portuguese.

6. Abreu MA, Reis PE, Gomes IP, Rocha PR. Non pharmacologic pain management on oncologic patients: systematic review. Online Braz J Nurs. 2009;8(1):[8 telas].

7. Benchaya I, Ferreira EA, Brasiliense IC. Efeitos de instruçăo e de treino parental em cuidadores de crianças com câncer. Psicol Teor Pesq. 2014;30(1):13-23.

8. Rheingans JI. A systematic review of nonpharmacologic adjunctive therapies for symptom management in children with cancer. J Pediatr Oncol Nurs. 2007;24(2):8194.

9. Higgins JP, Green S. (Editors). Cochrane Handbook for Systematic Reviews of Interventions Version 5.1.0 [updated March 2011]. The Cochrane Collaboration, 2011. Available from www.cochrane-handbook.org. Acesso em 30 de junho de 2014.

10. da Costa Santos CM, de Mattos Pimenta CA, Nobre MR. [The PICO strategy for the research question construction and evidence search]. Rev Lat Am Enfermagem 2007;15(3):508-11. Portuguese.

11. Jadad AR, Moore RA, Carroll D, Jenkinson C, Reynolds DJ, Gavaghan DJ, et al Assessing the quality of reports of randomized clinical trials: is blinding necessary? Control Clin Trials. 1996;17(1):1-12. 
12. Hedén L, Von Essen L, Ljungman G. Randomized interventions for needle procedures in children with cancer. Eur J Cancer Care. 2009;18(4):358-63.

13. Windich-Biermeier A, Sjoberg I, Dale JC, Eshelman D, Guzzetta CE. Effects of distraction on pain, fear, and distress during venous port access and venipuncture in children and adolescents with cancer. J Pediatr Oncol Nurs. 2007;24(1):8-19.

14. Wolitzky K, Fivush R, Zimand E, Hodges L, Rothbaum BO. Effectiveness of virtual reality distraction during a painful medical procedure in pediatric oncology patients. Psychol Health. 2005;20(6):817-24.

15. Gershon J, Zimand E, Pickering M, Rothbaum BO, Hodges L. A pilot and feasibility study of virtual reality as a distraction for children with cancer. J Am Acad Child Adolesc Psychiatry. 2004;43(10):1243-9.

16. Dahlquist LM, Pendley JS, Landthrip DS, Jones CL, Steuber CP. Distraction intervention for preschoolers undergoing intramuscular injections and subcutaneous port access. Health Psychol. 2002;21(1):94-9.
17. Broome ME, Rehwaldt M, Fogg L. Relationships between cognitive behavioral techniques, temperament, observed distress, and pain reports in children and adolescents during lumbar puncture. J Pediatr Nurs. 1998;13(1):48-54.

18. Manne SL, Bakeman R, Jacobsen PB, Gorfinkle K, Redd WH. An analysis of a behavioral intervention for children undergoing venipuncture. Health Psychol. 1994;13(6):556-66.

19. Manne SL, Redd WH, Jacobsen PB, Gorfinkle K, Schorr O. Behavioral intervention to reduce child and parent distress during venipuncture. J Consult Clin Psychol. 1990;58(5):565-72.

20. Smith KE, Ackerson JD, Blotcky AD. Reducing distress during invasive medical procedures: relating behavioral interventions to preferred coping style in pediatric cancer patients. J Pediatr Psychol. 1989;14(3):405-19.

21. Kuttner L, Bowman M, Teasdale M. Psychological treatment of distress, pain, and anxiety for young children with cancer. J Dev Behav Pediatr. 1988;9(6):374-81. 